\title{
AGENCY CONFLICT AND EARNINGS MANAGEMENT
}

\author{
Winston Pontoh ${ }^{1}$, Novi Swandari Budiarso ${ }^{2}$ \\ ${ }^{1,2}$ Accounting Study Program, Economics and Business Faculty, Sam Ratulangi University, Jl. Kampus Bahu, \\ Manado, 95115, Indonesia
}

Corresponding e-mail : winstonpontoh@unsrat.ac.id

\begin{abstract}
This conflict between firm insiders and firm outsiders in case to allocate the free cash still unclear in the context of agency theory. This study examines the sample of 25 public firms in consumer goods industry listed in Indonesia Stock Exchange over period of 2010 until 2018 in term to detect agency conflict with earnings management as its application. This study finds that discretionary accruals as the proxy of earnings management is insignificant on debt policy and growth opportunities. Those findings indicate that, Indonesian public firms do not practicing earnings management which means agency conflict is not exist over the sample of this study.
\end{abstract}

Keywords : agency conflict; earnings management; discretionary accruals; Indonesia

\section{INTRODUCTION}

The issues arround internal conflict between insiders and outsiders in context of agency theory have been testing by recent studies especially in field of finance and accounting. The internal conflict or agency conflict conceptually begins as firms have more profitable and large free cash which available for further profitable investments or to ditribute as dividends but managers tend to spend it for their own benefits (Jensen, 1988; Aivazian et al., 2005; Fairchild et al., 2014). The recent studies of Roychowdhury (2006), Cornett et al. (2008), An et al. (2016), and Alzoubi (2018) prove that earnings management as an application to detect agency conflict of the firms.

Most of the empirical findings of earnings management refers the ways of how to control the accounting report from such manipulations (Jones, 1991; Dechow et al., 1995; Roychowdhury, 2006). Most of empirical findings show that the earnings management practiced in two basis which called real activities which most focuses on expenses discretionary (Roychowdhury, 2006; Xue and Hong, 2016; Lo et al., 2017) and discretionary accruals which most focuses on accounting discretions (Jones, 1991; Dechow et al., 1995; Cornett et al., 2008; Lo et al., 2017).

As emerging market, the Indonesian firms are the good object to test the issues of agency conflict as this information will become basic consideration for investors to set strategies of investments. Some of local studies show the results of earnings management as the manifest of agency conflict in context of Indonesian firms (Nurim et al., 2017; Prihastomo and Khafid, 2018; Sunata and Haryanto, 2019).

The objective of this study is to provide empirical evidence whether Indonesian firms practice earnings management as the manifest of agency conflict. This study finds that the discretionary accruals is insignificant on debt and assets growth. Those results imply that Indonesian public firms especially in consumer goods industry not indicate for practicing earnings management in context of agency conflict. The next sections of this study are as follow: Section 2 reviews the literatures to develop hypotheses, Section 3 explains the research method of this study, Section 4 discusses the results of the study, and Section 5 concludes the findings of this study. 


\section{LITERATURE REVIEWS}

Agency theory. The basic theory of agency theory is theory of the firm which assumes that outsiders know about the input and output of the firms but uninform about how they process the input to become output (Jensen and Meckling, 1976). Under this assumption then Jensen and Meckling (1976) emphasize this circumstances as "black box" and at once raise the agency relationship. Jensen and Meckling (1976) define the agency relationship as a contract between outsiders as principals and insiders as agent where ideally agent will act on behalf of principals in term to maximize their value. The problem on agency relationship is rising while agents act not in-line with the interests of principals which refer to agency conflict (Jensen and Meckling, 1976).

Earnings management. Jones (1991) underlines that managers tend to practice the earnings management in objective to increase firm profits with motive to increase their compensation such as bonuses. The findings of Leuz et al. (2003) show that firm insiders tend to apply earnings management for private benefit in conditions that firms have weak investor protection, concentrated ownership, and stock markets are less developed, In addition, Leuz et al. (2003) also confirm that investor protection will determine the firm policies such as firms' financing and dividend policies. Similarly, Gopalan and Jayaraman (2012) also confirm that lower practice of earnings management by insiders for private benefits mostly found in firms with higher investor protection and more diversified ownership structure. Consistent with those findings, An et al. (2016) use earnings management as a proxy of agency conflict between insiders and outsiders.

Relationship between discretionary accruals and debt. Jensen (1986) convinces that stockholders use debt as disciplining action on managers in condition where managers behave on their own interests especially in case to allocate the free cash. Consistent with Jones (1991), the study of Christiawan and Rahmiati (2015) on Indonesian public firms during period of 2012 to 2013 find that managers tend to practice earnings management while firms have higher debt especially for long term debt. In addition, the study of Zamri et al. (2013) on Malaysian public firms during 2006 to 2011 find that abnormal cash flow from operations (CFO) negatively associates with debt which implies that debt able to reduce the practice of earnings management. Based on those literatures, this study posits that earnings management associates with higher debt.

H1: Earnings management positive significant on debt.

Relationship between discretionary accruals and growth opportunities. The study of Gopalan and Jayaraman (2012) on East Asian and European public firms over period of 1992 to 2006 find that good growth opportunities are able to mitigate the practice of earnings management by firm insiders. But, Jensen (1988), Aivazian et al. (2005), and Fairchild et al. (2014) also suggest that the source of agency conflict arise while the moral hazard of firm insiders tend to spend free cash on unprofitable investments which give them private benefit. Based on those literatures, this study posits that earnings management associates with growth opportunities in assumption that investments contains negative present value.

H2: Earnings management positive significant on growth opportunities.

\section{RESEARCH METHOD}

This study drawn the data from Indonesia Stock Exchange and uses 25 Indonesian public firms in consumer goods industry over period of 2010 to 2018 as sample. As the sample, this study selects by purposive the firms which published consistently audited annual financial report of all observe period, the firms should listed in capital market, and all data required for this study are available. Also, in term to keep the data consistently then this study excludes the firms who restate the financial report with significant changes. 
This study conducts multivariate analysis of covariance (MANCOVA) at significance of 5\% and therefore two dependent variables are used for hypothesis testing namely debt ratio and growth opportunities. This study uses debt ratio (measured by ratio of total debt over total asset and symbolized as DAR) as Jensen (1986) suggest this ratio plays the role as a control mechanism on firm insiders. This study follows Gopalan and Jayaraman (2012) to use growth opportunities in objective to detect the earnings management. Following Fairchild et al. (2014), this study uses assets growth (symbolized as AG) as proxy of growth opportunities. This study uses earnings management (symbolized as DA) and profitability (symbolized as ROA) as independent variables. This study adopts the model of Jones (1991) to capture the earnings management through estimated discretionary accruals and measures it by residuals of predicted model for each firms. The model of Jones (1991) is note as follows :

$$
\mathrm{TA}_{\mathrm{it}} / \mathrm{A}_{\mathrm{it}-1}=\alpha_{\mathrm{i}}\left(1 / \mathrm{A}_{\mathrm{it}-1}\right)+\beta_{\mathrm{i}}\left(\Delta \mathrm{REV}_{\mathrm{it}} / \mathrm{A}_{\mathrm{it}-1}\right)+\beta_{\mathrm{i}}\left(\Delta \mathrm{PPE} \mathrm{E}_{\mathrm{it}} / \mathrm{A}_{\mathrm{it}-1}\right)+\varepsilon_{\mathrm{it}}
$$

$\mathrm{TA}_{\mathrm{it}}$ is total accruals in year $\mathrm{t}$ for firm $\mathrm{i} ; \Delta \mathrm{REV}_{\mathrm{it}}$ is revenue difference of current year and previous year; $\mathrm{PPE}_{\mathrm{it}}$ is difference of acquisition cost of property, plant, and equipment of current year and previous year; $\mathrm{A}_{\mathrm{it}-1}$ is total assets of previous year; and $\varepsilon_{\mathrm{it}}$ is residual error. This study estimates total accruals $\left(\mathrm{TA}_{\mathrm{it}}\right)$ with model as follows:

$$
\mathrm{TA}_{\mathrm{t}}=\left(\Delta \mathrm{CA}_{\mathrm{t}}-\Delta \mathrm{Cash}_{\mathrm{t}}\right)-\left(\Delta \mathrm{CL}_{\mathrm{t}}-\mathrm{DepExp}_{\mathrm{t}}\right)
$$

$\Delta \mathrm{CA}_{\mathrm{t}}$ is difference of current assets between current year and previous year; $\Delta \mathrm{Cash}_{\mathrm{t}}$ is difference of cash between current year and previous year; $\Delta \mathrm{CL}_{\mathrm{t}}$ is difference of current liabilities (exclude tax payables and part of long-term debt) of current year and previous year; and DepExp $\mathrm{p}_{\mathrm{t}}$ is depreciation plus amortization expense of current year. This study also uses profitability as the control variable which measured by dummy and calculated based on median of average return on assets of each firms. The dummy of profitability is 1 if above or equal to median and 2 for vise versa, where the median of average return on assets of each firms is 0.097170631 .

\section{RESULTS AND DISCUSSIONS}

\subsection{Results}

Table 1 presents the result of descriptive statistics of this study with control of profitability. The results of mean show that firms with higher profitability have lower debt ratio relative to firms with lower profitability which indicates earnings management possibly less practiced for those firms. Furthermore, firms with higher profitability also have more growth opportunities as reflected by their assets growth rather than firms with lower profitability which indicates those firms spend more for investments to reduce practice of earnings management. But, the mean of DA shows that both firms have zero value which indicates neither those firms practicing earnings management.

Table 1. Descriptive statistics

\begin{tabular}{lccccc}
\hline Variables & ROA & Mean & Minimum & Maximum & N \\
\hline DAR & 1.00 & 0.3397 & 0.09 & 0.75 & 117 \\
& 2.00 & 0.4629 & 0.13 & 1.25 & 108 \\
AG & 1.00 & 0.1355 & -0.10 & 0.64 & 117 \\
& 2.00 & 0.1321 & -0.16 & 0.82 & 108 \\
DA & 1.00 & 0.0000 & -1.73 & 1.59 & 117 \\
& 2.00 & 0.0000 & -1.67 & 1.64 & 108 \\
\hline
\end{tabular}

Notes: DAR is debt ratio and measured by ratio of total debt over total asset. AG is assets growth and measured by difference of current year total assets and previous year total assets divided by previous year total assets. DA is discretionary accruals and estimated by residuals of predicted model for each firms. 
This study continue to run homogeneity test of covariances before conducts multivariate analysis of covariance (MANCOVA). Table 2 shows that the $\mathrm{F}$ test is insignificant on Box's test which means the data of the model for this study is homogent. On this result, then this study can continue to analyze the data by MANCOVA.

Table 2. Result of Box's Test of Equality of Covariance Matrices

\begin{tabular}{lr} 
Box's M & 6.657 \\
df1 & 2.197 \\
df2 & 3 \\
Sig. & 11255176.449 \\
\hline
\end{tabular}

Table 3 shows the result of multivariate analysis of covariance (MANCOVA) for the effect of discretionary accruals on debt ratio and assets growth. The results show that discretionary accruals insignificant on debt ratio and also on assets growth. The results also show that profitability insignificant on assets growth but significant on debt ratio.

Table 3. Result of multivariate analysis of covariance

\begin{tabular}{|c|c|c|c|c|c|c|}
\hline Source & $\begin{array}{l}\text { Dependent } \\
\text { Variable }\end{array}$ & $\begin{array}{l}\text { Type III } \\
\text { Sum of } \\
\text { Squares }\end{array}$ & df & $\begin{array}{l}\text { Mean } \\
\text { Square }\end{array}$ & $\mathbf{F}$ & Sig. \\
\hline \multirow[t]{2}{*}{ Corrected Model } & DAR & $0.853^{\mathrm{a}}$ & 2 & 0.427 & 14.906 & 0.000 \\
\hline & $\mathrm{AG}$ & $0.010^{\mathrm{b}}$ & 2 & 0.005 & 0.228 & 0.796 \\
\hline \multirow[t]{2}{*}{ Intercept } & DAR & 36.176 & 1 & 36.176 & 1264.046 & 0.000 \\
\hline & $\mathrm{AG}$ & 4.022 & 1 & 4.022 & 192.385 & 0.000 \\
\hline \multirow[t]{2}{*}{ DA } & DAR & 0.001 & 1 & 0.001 & 0.035 & 0.852 \\
\hline & AG & 0.009 & 1 & 0.009 & 0.424 & 0.516 \\
\hline \multirow[t]{2}{*}{ ROA (dummy) } & DAR & 0.852 & 1 & 0.852 & 29.776 & 0.000 \\
\hline & $\mathrm{AG}$ & 0.001 & 1 & 0.001 & 0.032 & 0.858 \\
\hline \multirow[t]{2}{*}{ Error } & DAR & 6.353 & 222 & 0.029 & & \\
\hline & $\mathrm{AG}$ & 4.642 & 222 & 0.021 & & \\
\hline \multirow[t]{2}{*}{ Total } & DAR & 42.997 & 225 & & & \\
\hline & $\mathrm{AG}$ & 8.684 & 225 & & & \\
\hline \multirow[t]{2}{*}{ Corrected Total } & DAR & 7.207 & 224 & & & \\
\hline & $\mathrm{AG}$ & 4.651 & 224 & & & \\
\hline
\end{tabular}

a. R Squared $=0.118$ (Adjusted R Squared $=0.110$ )

b. $R$ Squared $=0.002$ (Adjusted R Squared $=-0.007$ )

Notes: DAR is debt ratio and measured by ratio of total debt over total asset. AG is assets growth and measured by difference of current year total assets and previous year total assets divided by previous year total assets. DA is discretionary accruals and estimated by residuals of predicted model for each firms.

\subsection{Discussions}

Relationship between discretionary accruals and debt. The result on Table 3 shows that discretionary accruals insignificant on debt ratio which means this study rejects $\mathrm{H} 1$. This result indicates that earnings management is not practiced by Indonesian public firms in consumer goods industry. On this finding, then this study is not consistent with Jensen (1986) which implies that shareholders of those firms do not use debt as a tool to control the managers. The finding of this study also inconsistent with the finding of Zamri et al. (2013) and Christiawan and Rahmiati (2015) and confirms that there is no agency conflict on Indonesian public firms in consumer goods industry. 
Relationship between discretionary accruals and growth opportunities. The result on

Table 3 shows that discretionary accruals insignificant on assets growth which means this study rejects $\mathrm{H} 2$. The finding of this study inconsistent with the finding of Gopalan and Jayaraman (2012) and at once confirm the result for H1 which indicates that Indonesian public firms limited to the sample of this study do not practicing earnings management. Inconsistent with the findings of Jensen (1988), Aivazian et al. (2005), and Fairchild et al. (2014), this study also confirms that the managers do not have tendency to spend free cash on unprofitable investments for their own benfits which means there is no agency conflict as confirmed by the result of $\mathrm{H} 1$.

Furthermore, Table 3 shows that profitability as control variable is insignificant on assets growth which implies that shareholders do not tend to rise the investments as they are concern about manager's moral hazard. Reversely, Table 3 shows that profitabiliy is significant on debt ratio. As the resulta of discretionary accruals show inconsistency with agency conflict then this result possibly refers to the case of tax shield. According to Modigliani and Miller (1958), as the tax-payers then firms normally looking for the tax shield for their income and set certain debts as an alternative. On this case, Modigliani and Miller (1958) refer to trade-off theory in relationship with capital structure. Myers (2001) confirms that the income tax of firms practially based on profits which means more profits then higher the income tax.

\section{CONCLUSION}

The objective of this study is to analyze whether Indonesian firms practice earnings management as the manifest of agency conflict. This study finds that the discretionary accruals are insignificant on debt and assets growth which indicate that firms limited to sample of this study are less practicing earnings management. This findings also imply that agency conflict for Indonesian public firms in consumer goods industry is not exist. This study suggests that further studies in same area to include the relationship between earnings management and firm dividend policy.

\section{REFERENCES}

Aivazian, V. A., Ge, Y., \& Qiu, J. (2005). The impact of leverage on firm investment : Canadian evidence. Journal of Corporate Finance, 11, 277-291. https://doi.org/10.1016/S0929-1199(03)00062-2

Alzoubi, E. S. S. (2018). Audit quality, debt financing, and earnings management: Evidence from Jordan. Journal of International Accounting, Auditing and Taxation, 30, 69-84. https://doi.org/10.1016/j.intaccaudtax.2017.12.001

An, Z., Li, D., \& Yu J. (2016). Earnings management, capital structure, and the role of institutional environments. Journal of Banking and Finance, 68, 131-152. https://doi.org/10.1016/j.jbankfin.2016.02.007

Christiawan, Y. J., \& Rahmiati, A. (2015). Earnings management of firms reporting long term debt: An alternative method. Jurnal Akuntansi dan Keuangan, 16(2), 113-120. doi:https://doi.org/10.9744/jak.16.2.113-120

Cornett, M. M., Marcus, A. J., \& Tehranian, H. (2008). Corporate governance and pay-forperformance: The impact of earnings management. Journal of Financial Economics, 87(2), 357-373. https://doi.org/10.1016/j.jfineco.2007.03.003

Dechow, P. M., Sloan, R. G., \& Sweeney, A. P. (1995). Detecting earnings management. The Accounting Review, 70(2), 193-225. https://www.jstor.org/stable/248303 
Fairchild, R., Guney, Y., \& Thanatawee, Y. (2014). Corporate dividend policy in Thailand : Theory and evidence. International Review of Financial Analysis, 31, 129-151. https://doi.org/10.1016/j.irfa.2013.10.006

Gopalan, R. \& Jayaraman, S. (2012). Private control benefits and earnings management: Evidence from insider controlled firms. Journal of Accounting Research, 50, 117-157. https://doi.org/10.1111/j.1475-679X.2011.00431.x

Jensen, M. C. (1986). Agency costs of free cash flow, corporate finance, and takeovers. American Economic Review, 76(2), 323-329. http://www.jstor.org/stable/1818789

Jensen, M. C. (1988). Takeovers : Their causes and consequences. The Journal of Economic Perspectives, 2(1), 21-48. https://doi.org/10.1257/jep.2.1.21

Jensen, M. C., \& Meckling, W. H. (1976). Theory of the firm: Managerial behavior, agency costs and ownership structure. Journal of Financial Economics, 3(4), 305-360. https://doi.org/10.1016/0304-405X(76)90026-X

Jones, J. J. (1991). Earnings management during import relief investigations. Journal of Accounting Research, 29(2), 193-228. https://doi.org/10.2307/2491047

Leuz, C., Nanda D., \& Wysocki, P. D. (2003). Earnings management and investor protection: An international comparison. Journal of Financial Economics, 69(3), 505-527. https://doi.org/10.1016/S0304-405X(03)00121-1

Lo, K., Ramos, F., \& Rogo, R. (2017). Earnings management and annual report readability. Journal of Accounting and Economics, 63(1), 1-25. http://dx.doi.org/10.1016/j.jacceco.2016.09.002

Modigliani, F., \& Miller, M. H. (1958). The cost of capital, corporation finance and the theory of investment. The American Economic Review, 48(3), 261-297. http://www.jstor.org/stable/1809766

Myers, S. C. (2001). Capital structure. The Journal of Economic Perspectives, 15(2), 81-102. http://www.jstor.org/stable/2696593

Nurim, Y., Sunardi, S., \& Raharti, R. (2017). The Type I versus Type II agency conflict on earnings management. Jurnal Dinamika Manajemen, 8(1), 44-58. https://doi.org/10.15294/jdm.v8i1.10410

Prihastomo, E. D., \& Khafid, M. (2018). The effect of bonus compensation and leverage on earnings management with financial performance as intervening variable. Accounting Analysis Journal, 7(1), 52-60. http://doi.org/10.15294/aaj.v5i3.18490

Roychowdhury, S. (2006). Earnings management through real activities manipulation. Journal of Accounting and Economics, 42(3), 335-370. https://doi.org/10.1016/j.jacceco.2006.01.002

Sunata, M., \& Haryanto, M. (2019). The influence of corporate governance mechanism on earnings management. Jurnal Ilmiah Bisnis, Pasar Modal dan UMKM, 2(1), 74-88. https://ibn.e-journal.id/index.php/JIBPU/article/view/122

Xue S., \& Hong Y. (2016). Earnings management, corporate governance and expense stickiness. China Journal of Accounting Research, 9(1), 41-58. https://doi.org/10.1016/j.cjar.2015.02.001

Zamri, N., Rahman, R. A., \& Isa, N. S. M. (2013). The Impact of Leverage on Real Earnings Management. Procedia Economics and Finance, 7, 86-95. https://doi.org/10.1016/s2212-5671(13)00222-0 